\title{
Colony Diet Influences Ant Worker Foraging and Attendance of Myrmecophilous Lycaenid Caterpillars
}

\author{
Sebastian Pohl ${ }^{1,2}$, Megan E. Frederickson ${ }^{2 \dagger}$, Mark A. Elgar ${ }^{1 *}$ and Naomi E. Pierce ${ }^{2}$ \\ ${ }^{1}$ School of BioSciences, Faculty of Science, The University of Melbourne, Parkville, VIC, Australia, ${ }^{2}$ Department of \\ Organismic and Evolutionary Biology, Harvard University, Cambridge, MA, USA
}

\section{OPEN ACCESS}

Edited by:

Peter Schausberger,

University of Vienna, Austria

Reviewed by:

Spencer T. Behmer,

Texas A\&M University, USA

Konrad Fiedler,

University of Vienna, Austria Kleber Del Claro

Universidade Federal de Uberlândia,

Brazil

${ }^{*}$ Correspondence:

Mark A. Elgar

m.elgar@unimelb.edu.au

${ }^{\dagger}$ Present Address:

Megan E. Frederickson,

Department of Ecology and

Evolutionary Biology, University of Toronto, 25 Willcocks Street, Toronto,

Ontario M5S 3B2, Canada

Specialty section:

This article was submitted to Behavioral and Evolutionary Ecology,

a section of the journa

Frontiers in Ecology and Evolution

Received: 10 June 2016 Accepted: 13 September 2016 Published: 28 September 2016

Citation:

Pohl S, Frederickson ME, Elgar MA and Pierce NE (2016) Colony Diet Influences Ant Worker Foraging and Attendance of Myrmecophilous Lycaenid Caterpillars.

Front. Ecol. Evol. 4:114. doi: 10.3389/fevo.2016.00114
Foraging animals regulate their intake of macronutrients such as carbohydrates and proteins. However, regulating the intake of these two macronutrients can be constrained by the nutrient content of available food sources. Compensatory foraging is a method to adjust nutrient intake under restricted nutrient availability by preferentially exploiting food sources that contain limiting nutrients. Here we studied the potential for compensatory foraging in the dolichoderine ant Iridomyrmex mayri, which is commonly found in associations with caterpillars of the obligatorily ant-associated lycaenid butterfly Jalmenus evagoras. The caterpillars receive protection against predators and parasites, and reward the ants with nutritional secretions from specialized exocrine glands. These secretions contain a mixture of sugars and free amino acids, particularly serine. We tested the influence of nutrient-deficient diets on foraging patterns in I. mayri by recording the intake of test solutions containing single types of macronutrients during food preference tests. We also investigated the level of ant attendance on fifth instar J. evagoras caterpillars to evaluate how changes in diet influenced ant tending of caterpillars and foraging on their secretions. Foragers on a protein diet compensated for the nutritional deficit by increasing the intake of test solutions that contained sucrose, compared to their counterparts on a non-restricted diet. Ants on a sugar diet, however, did not show a corresponding increased consumption of test solutions containing the amino acid serine. Additionally, compared with their counterparts on a mixed diet, ants on limited nutrient diets showed an increase in the number of caterpillar-tending workers, suggesting that the caterpillars' secretions are suitable to compensate for the ants' nutritional deficit.

Keywords: compensatory foraging, geometric framework, nutritional status, species interaction, mutualism, symbiosis

\section{INTRODUCTION}

The "Geometric Framework" (Simpson and Raubenheimer, 2012) provides a compelling theoretical approach to understanding foraging strategies, by assuming that animals have intake targets for all relevant nutrients, and thus predicting the simultaneous regulation of nutrient intake to meet particular target ratios (e.g., relative proportions of protein and carbohydrates) 
for individual organisms (Simpson and Raubenheimer, 1993; Raubenheimer and Simpson, 1999; Simpson et al., 2004; Raubenheimer et al., 2009). This approach has been successfully applied to a range of species, from slime molds, through insects to humans (Raubenheimer and Simpson, 1993; Simpson et al., 2003; Behmer, 2009; Dussutour et al., 2010), and furthered the understanding of nutritional dynamics and trophic interactions (Simpson et al., 2015).

While solitary animals must satisfy their own nutritional needs, food acquisition in social insects requires a more complex evaluation of specific target ratios, due to their colonial lifestyle as well as accommodating the varying nutritional needs of different colony members. Ant larvae, for example, require a proteinbased diet for successful development, whereas a sugar-based diet is sufficient for worker survival (Hölldobler and Wilson, 1990). Social insect foragers must take into account the varying nutritional needs of different castes when searching for food, while also responding to potential nutrient restrictions in the food currently available to the colony (Seeley, 1989; Cassill and Tschinkel, 1999a). One way to compensate for nutritional deficits is compensatory foraging, in which workers adjust their preferences in favor of food sources containing limiting nutrients. Nutrient compensatory foraging ensures that the colony meets its longer-term targets and thus facilitates colony growth and reproductive output. Evidence of nutrient compensatory foraging is provided by both field and laboratory studies of honey bees (Hendriksma and Shafir, 2016) and several species of ants, including Solenopsis invicta (Sorensen et al., 1985; Cook et al., 2010; Wilder and Eubanks, 2010), Rhytidoponera metallica (Dussutour and Simpson, 2008), Ectatomma ruidum (Cook and Behmer, 2010), and Iridomyrmex suchieri (Christensen et al., 2010).

The Australian ant genus Iridomyrmex (Formicidae: Dolichoderinae) contains numerous taxa that are ecologically dominant, "agricultural" species that tend extra-floral nectaries and nectar-secreting insects such as hemipterans and the caterpillars of lycaenid butterflies. Iridomyrmex ants are often found in association with caterpillars and pupae of the obligatorily ant-associated lycaenid butterfly Jalmenus evagoras (Braby, 2000). The ant workers provide juveniles of J. evagoras with protection against parasites and predators (Pierce et al., 1987), and in turn are rewarded with nutritional secretions from the dorsal nectary organ, a specialized exocrine gland of the butterfly larvae, as well as from single celled epidermal glands called pore cupolae that are found in the epidermis of larvae and pupae (Kitching, 1983; Pierce and Nash, 1999). Although colonies of Iridomyrmex attendant ant species occur in the absence of $J$. evagoras and do not depend exclusively on lycaenids for nutrition (Pierce et al., 1987; Smiley et al., 1988), the secretions can account for a considerable proportion of the overall food intake of an ant colony whose workers tend aggregations of larvae and pupae of J. evagoras (Pierce et al., 1987). In another association between lycaenid caterpillars and ants, a medium-sized colony of Tetramorium caespitum can acquire $47 \%$ of its energy demand from secretions by caterpillars of Polyommatus coridon found within its territory (Fiedler and Maschwitz, 1988). Analyses of proteins and sugars from secretions of J. evagoras show that they comprise a mixture of sugars, mainly sucrose and fructose, and up to 14 different free amino acids, particularly serine (Pierce, 1985; Pierce and Nash, 1999). The secretions have yet to be analyzed for additional compounds that may also play a role in mediating interactions with ants (cf. Hojo et al., 2015).

The presence of sugars in combination with relatively high concentrations of a single amino acid in the secretions of anttended lycaenid larvae raises the intriguing possibility of larvae providing compensatory nutrients to their tending ants that allow the colony to meet their nutrient intake targets. Providing both proteins and carbohydrates hence may be an important feature of the mutualism between ant-associated lycaenids and their attendant ants (Wada et al., 2001; Hojo et al., 2008) because it guarantees a more consistent reward value than a single nutrient. Interestingly, caterpillars of Niphanda fusca secrete high concentrations of glycine, which in combination with sugars is extremely attractive to their host ants, Camponotus japonicus. Neither the sugars nor glycine are as attractive alone as when presented together, suggesting that they may act synergistically to attract C. japonicus attendant ants (Wada et al., 2001; Hojo et al., 2008).

The aim of the present study was two-fold. First we investigated whether compensatory feeding occurs in the caterpillar-tending dolichoderine ant I. mayri. We kept ant colony fragments on either a sugar- or protein-deficient diet and measured their intake of test solutions containing sucrose and/or serine in food preference tests. We predicted that the ants would compensate for a deficit of specific macronutrients by increasing the intake of test solutions that contained the component missing in their diet.

We then examined whether this diet conditioning influenced the number of foragers of I. mayri tending caterpillars of J. evagoras. We asked whether workers change their tending efforts according to their colony's nutritional state, and whether such potential differences in caterpillar tending depend on the respective nature of the nutritional deficit. We predicted an increase in caterpillar tending as compensation for the ants' nutrient-deficient diets, whether the deficiency was in carbohydrates on the one hand or proteins on the other.

\section{MATERIALS AND METHODS}

\section{Study Species}

The systematics of the ant genus Iridomyrmex has been problematic for many years (Heterick and Shattuck, 2011; Andersen et al., 2013), and this is reflected in the identification of ants associated with Jalmenus evagoras. The species of ants used in this study were identified by Bob Taylor at CSIRO initially as $I$. sp. 25 (his reference number), and later as $I$. anceps, but subsequently Alan Greenslade at CSIRO placed them as I. gracilis. This identification was further revised by Alan Anderson (Eastwood et al., 2006; Hoffmann et al., 2011), and in Heterick and Shattuck (2011), the name I. gracilis was dissolved. More recently, Steve Shattuck has examined our samples carefully, and has identified them as I. mayri. Voucher specimens have been 
deposited in the DNA and Tissues collection of the Museum of Comparative Zoology at Harvard University.

\section{Ant Colony Maintenance and Feeding Treatments}

Workers, larvae and eggs (but not queens) of I. mayri were collected from eight different colonies in January 2001 from Mt. Nebo, Queensland, Australia, where they co-exist with Jalmenus evagoras. The colonies were maintained in the laboratory on a standard ant diet (Bhatkar and Whitcomb, 1970), supplemented with frozen crickets (Fluker's Cricket Farm, Port Allen, LA, USA), and water. In advance of the experiments, colonies were switched to a mixed diet, supplied ad libitum, consisting of a $0.5 \mathrm{~mol} / \mathrm{l}$ sucrose solution, chopped crickets, and water, and kept under these conditions for 7-22 days. Subsequently, all colonies were divided into three equal colony fragments, each consisting of approximately 2000 workers and roughly equivalent amounts of brood (eggs, larvae and pupae) by weight. We included ant larvae in the colony fragments as there are differences in the nutritional needs between ant larvae and workers (Brian, 1973; Howard and Tschinkel, 1981; Porter, 1989; Evans and Pierce, 1995; Cassill and Tschinkel, 1999b), and the presence of larvae improves the regulation of food intake (Dussutour and Simpson, 2008, 2009). The colony fragments were provided with the mixed diet for a further 8-14 days, after which the first round of food preference tests (pre-restriction tests) took place. The colony fragments then were assigned to one of three different feeding treatments: The control fragment was kept on the previous diet (mixed diet, M), whereas the two other fragments of each colony were subjected to a restricted diet of $0.5 \mathrm{~mol} / \mathrm{l}$ sucrose (sugar diet) or chopped crickets (protein diet), respectively, until the end of the experiment after 31 days. All treatment groups were supplied with water ad libitum. For each colony, food was provided in a foraging arena, and was connected to the nesting box via a clear plastic tubing runway of approximately $30 \mathrm{~cm}$ length.

\section{Food Preference}

Food preference was tested at 0 (pre-restriction tests), 2, 7, 14, and 31 (post-restriction tests) days after the onset of the feeding treatments. Four different test solutions of $100 \mathrm{mg}$ each were presented simultaneously in separate small plastic petri dishes (diameter: $5 \mathrm{~cm}$ ): $0.5 \mathrm{~mol} / \mathrm{l}$ sucrose solution, 0.05 $\mathrm{mol} / \mathrm{l}$ serine (Sigma-Aldrich, St. Louis, $\mathrm{MO}$ ) solution, $0.5 \mathrm{~mol} / \mathrm{l}$ sucrose $+0.05 \mathrm{~mol} / \mathrm{l}$ serine solution (sucrose + serine), and water. Test solutions were presented in the foraging arena (see above). Serine was chosen as a protein-related nutrient, since it is the main amino acid secreted by the dorsal nectary organ of $J$. evagoras caterpillars, and workers of I. mayri prefer it to most other amino acids in choice experiments (Pierce, 1989). The duration of the tests varied with forager activity (median: $40 \mathrm{~min}$, range: $13-107 \mathrm{~min}, N=40$ ); petri dishes were removed before the first solution was consumed completely, and subsequently weighed to determine the amount of consumption. Consumed amounts were then adjusted to the test duration for subsequent data analyses.

\section{Caterpillar Attendance}

In addition to the food preference tests, all colony fragments were subjected to a bioassay with J. evagoras caterpillars on each of the testing days. Eggs of J. evagoras were collected in January from Ebor, New South Wales, Australia, and caterpillars were reared without ants in the greenhouse on cuttings from potted host plants of Acacia melanoxylon that had been grown from seed in the greenhouse. We quantified the tending behavior of workers of I. mayri by observing their interactions with J. evagoras caterpillars. The caterpillar was placed in the otherwise cleared foraging arena, and after $30 \mathrm{~min}$ we counted the number of ants actively tending the caterpillar, defined as standing on and directly grooming or licking the caterpillar. Ants standing nearby or surrounding the caterpillar were not included. We used 56 th-instar caterpillars (weight range: $60.51-319.22 \mathrm{mg}$, median: $170.62 \mathrm{mg}$ ) that were individually labeled to control for the influence of a caterpillar individual on the experimental result. Caterpillar weight was used as a measure of attractiveness to the ants, since bigger caterpillars attract more ants (Pierce et al., 1987). Each individual caterpillar was tested with ants from a maximum of two different colonies, and with ants of all three colony fragments within a colony.

The research reported in this paper, which involved insects only, was exempt from ethical approval procedures.

\section{Data Analysis}

All analyses were performed with SPSS version 21 (IBM). To analyze the data from the food preference tests, we built a generalized linear mixed model, using the consumption of the test solution (in $\mathrm{mg} / \mathrm{min}$ ) as the target variable. Based on corrected AIC scores, the chosen model used a normal distribution with an identity link function for the target. We included diet, test solution, days after restriction, and the prerestriction consumption of the test solution (in $\mathrm{mg} / \mathrm{min}$ ) as fixed effects. All main effects, all 2-way and 3-way interactions between diet, test solution and days after restriction as well as the intercept were included. Two random effect blocks were created. The first one used colony as subject, the second one colony fragment nested in colony. Both random effect blocks included the intercept and used variance component as random effect covariance type. For post-estimation, degrees of freedom were calculated using the Satterthwaite approximation and tests of fixed effects and coefficients used model-based covariances. For significant interactions between categorical effects, we determined pairwise contrasts and estimated means for the target using mean values for continuous effects. We employed sequential Bonferroni adjustments for multiple comparisons.

Subsequently, we built univariate general linear models separately for every diet, to further investigate the effect of the number of days after restriction. We used the consumption of the test solution (in $\mathrm{mg} / \mathrm{min}$ ) as the dependent variable, days after restriction and test solution as fixed factors, and colony as a random factor. All main effects and all 2-way interactions as well as the intercept were included in the model.

To analyze caterpillar attendance, we built a generalized linear mixed model, using the number of ants attending the caterpillar after $30 \mathrm{~min}$ as the target variable. Based on corrected AIC scores, 
the chosen model used a Poisson distribution with a log link function for the target. We included diet, days after restriction, and caterpillar weight (in mg) as fixed effects. All main effects and all 2-way interactions between the fixed effects as well as the intercept were included. Three random effect blocks were created. The first one used colony as subject, the second one colony fragment nested in colony. The third random effect block used caterpillar ID as terms and colony fragment nested in colony as subject. All three random effect blocks included the intercept and used variance component as random effect covariance type. For post-estimation, degrees of freedom were calculated using the Satterthwaite approximation and tests of fixed effects and coefficients used model-based covariances. For the categorical effect "diet," we determined pairwise contrasts and estimated means for the target using mean values for continuous effects. We employed sequential Bonferroni adjustments for multiple comparisons.

\section{RESULTS}

\section{Food Preference}

We found an interaction effect between diet and the type of test solution on test solution consumption $\left[F_{(6,347)}=2.316\right.$, $p=0.033$; Table 1]. Pairwise contrasts showed that for colony fragments on a protein diet, consumption of sucrose and sucrose + serine solutions was higher than consumption of serine solution and water (all $p<0.001$; Figure 1, Table S1), but there was no difference in consumption between sucrose and sucrose + serine solutions $(p>0.999)$ or between serine solution and water $(p>0.999)$. Colony fragments on a sugar diet or a mixed diet did not show differential intake of test solutions (all $p>0.999$; Table S1).

Furthermore, we found an interaction effect between diet and the number of days after restriction $\left[F_{(2,346)}=14.474\right.$, $p<0.001$; Table 1]. Accordingly, we subsequently analyzed the influence of the time since diet implementation on the consumption of the different test solutions, separately for the different diets. We found an interaction between test solution and days after restriction $\left[F_{(9,60)}=9.605, p<0.001\right.$; Figure 2, Table 2]. For all test solutions, the consumption increased with days after restriction. Two days after restriction, consumption of

TABLE 1 | Test statistics for the generalized linear mixed model with consumption of the test solution as the target variable.

\begin{tabular}{lrrrr}
\hline & $\boldsymbol{F}$ & $\boldsymbol{d f 1}$ & $\boldsymbol{d f 2}$ & $\boldsymbol{p}$ \\
\hline Corrected model & 17.424 & 24 & 353 & $<0.001$ \\
Diet & 8.312 & 2 & 346 & $<0.001$ \\
Test solution & 1.667 & 3 & 347 & 0.174 \\
Days after restriction & 87.065 & 1 & 346 & $<0.001$ \\
Pre-restriction consumption & 0.659 & 1 & 261 & 0.418 \\
Diet * Test solution & 2.316 & 6 & 347 & 0.033 \\
Diet * Days after restriction & 14.474 & 2 & 346 & $<0.001$ \\
Test solution * Days after restriction & 1.947 & 3 & 346 & 0.122 \\
Diet * Test solution * Days after restriction & 1.439 & 6 & 346 & 0.199
\end{tabular}

sucrose + serine solution was higher than water consumption; starting from 7 days after restriction, the consumption of sucrose and sucrose + serine solutions was higher than the consumption of both serine solution and water (all comparisons based on overlapping of 95\% confidence intervals; Figure 2). For colony fragments on a sugar diet or mixed diet, we found in each case only significant interaction effects between colony and days after restriction (both $p<0.001$; all other $p>0.39$ ).

\section{Caterpillar Attendance}

The number of ants attending the caterpillar after 30 min differed between diets $\left[F_{(2,179)}=5.092, p=0.007\right.$; Figure 3, Table 3A $]$. Pairwise contrasts showed that the number of attending ants differed between all three diets (all $p<0.001$; Table 3B). Furthermore, the number of attending ants increased with increasing caterpillar weight [fixed effects: $F_{(1,178)}=24.662$, $p<0.001$; fixed coefficients: coefficient $=0.002$, standard error $=0.001, t=3.438, p<0.001]$.

\section{DISCUSSION}

Our experiments showed that foragers of I. mayri change their foraging behavior in response to diet restriction. In food preference experiments, ants on a protein diet increased their intake of test solutions containing sucrose compared with ants on sugar or mixed diets. However, workers on a sugar diet did not similarly increase the intake of test solutions containing the amino acid serine, which is the primary amino acid secreted

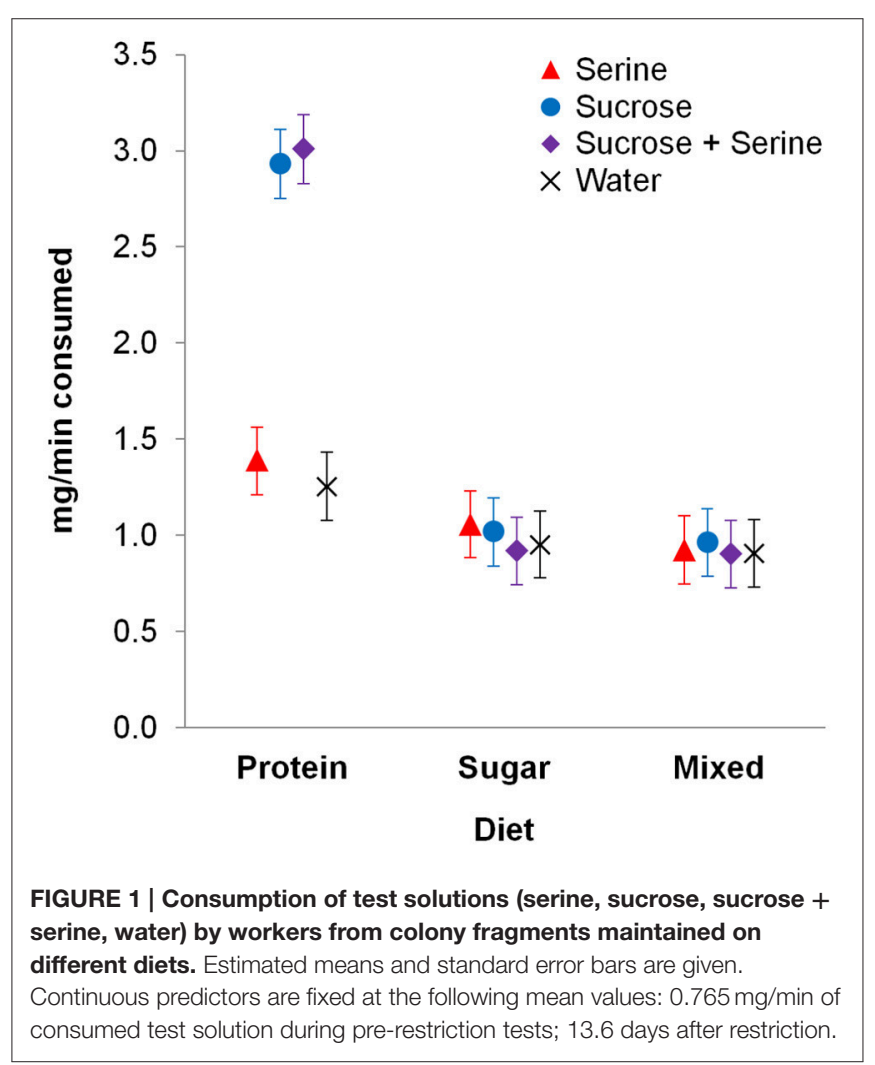




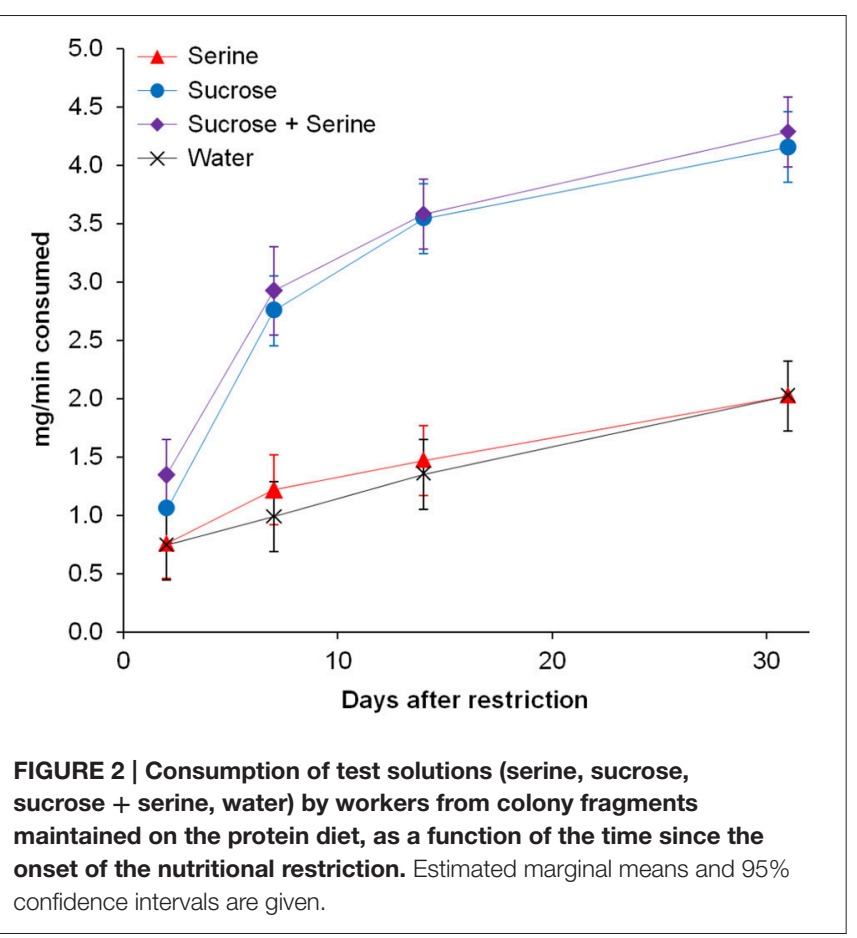

TABLE 2 | Test statistics for the general linear model with the consumption of test solutions as dependent variable, for colony fragments on the protein diet.

\begin{tabular}{lccr}
\hline & $\boldsymbol{d f}$ & $\boldsymbol{F}$ & $\boldsymbol{p}$ \\
\hline Intercept & $1,7.007$ & 179.995 & $<0.001$ \\
Test solution & $3,21.410$ & 115.007 & $<0.001$ \\
Days after restriction & $3,21.019$ & 4.984 & 0.009 \\
Colony & $7,21.420$ & 0.601 & 0.749 \\
Test solution * Days after restriction & 9,60 & 9.605 & $<0.001$ \\
Test solution * Colony & 21,60 & 1.315 & 0.203 \\
Days after restriction * Colony & 21,60 & 28.699 & $<0.001$ \\
\hline
\end{tabular}

by the dorsal nectary organ of J. evagoras. These data suggest that carbohydrate deprivation can serve as a trigger for foraging activity in I. mayri. Caterpillar attendance by workers of I. mayri similarly depends upon their dietary history: the number of workers tending J. evagoras caterpillars was highest for ants on a protein diet, followed by ants on a sugar diet, while ants on a mixed diet had the least number of tending workers. This demonstrates that the ants treat the caterpillars as a colony-level food source (Pierce et al., 1987) that can compensate for their nutritional deficit.

Food sources offering carbohydrates are often more attractive to foraging ants than protein baits, and preferences for carbohydrates can be increased by feeding protein-rich diets (Fourcassié and Traniello, 1994; Kay, 2004; Christensen et al., 2010). For example, experiments with the ant species Rhytidoponera metallica showed that workers can regulate their carbohydrate consumption to achieve intake targets by modifying both ingestion and recruitment based on the

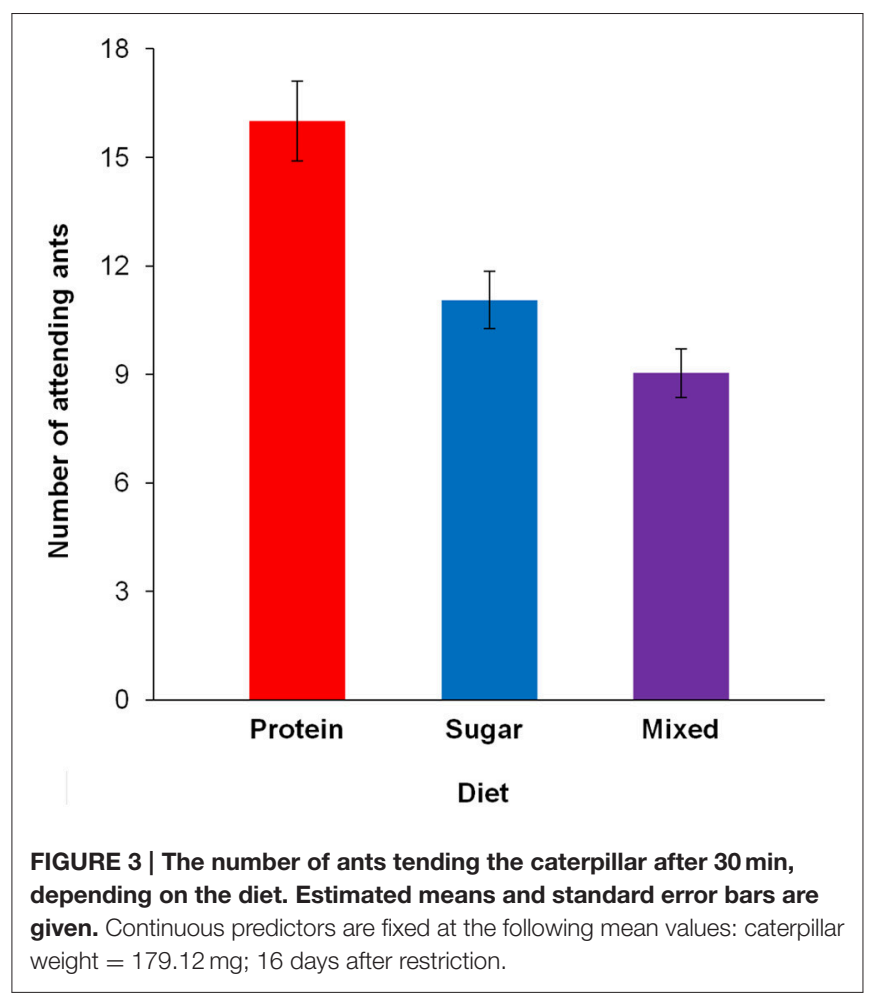

concentration of carbohydrates in their diet (Dussutour and Simpson, 2008). Furthermore, they were able to extract carbohydrates and eject protein from a mixed food source to balance their nutritional needs (Dussutour and Simpson, 2009).

Interestingly, protein-deprivation did not precipitate a preference by workers of $I$. mayri for serine. It is unlikely that the workers of I. mayri did not perceive serine as a nutrient, since they prefer serine over other amino acids in choice experiments under field conditions (Pierce, 1989). While serine may be a limiting nutrient in the field, leading to preferential intake of serine solutions under otherwise unrestricted food access, serine alone may be insufficient to compensate for any protein deficiencies resulting in the observed indifference to solutions containing only serine. Indeed, free-living foragers of Formica exsectoides preferred in mid-season a mixture of amino acids over single amino acid solutions (Bristow and Yanity, 1999), and numerous tropical Australian ant species preferred sugarbased solutions with a mixture of several amino acids over those with single amino acids, while they showed no preference for single amino acid solutions over solutions containing only sugar (Blüthgen and Fiedler, 2004).

While all experimental colony fragments contained ant larvae and should hence need to forage for proteins to support larval growth, it is also possible that workers on the protein-deficient diet consumed part of the brood as a source of compensatory nutrients (Wilson, 1971) and thus were not, in fact, protein deficient. We cannot evaluate this possibility because we did not monitor brood numbers during the course of the experiment. Alternatively, the absence of the queen in our colony fragments may have influenced the foraging decisions of the workers. 
TABLE 3 | Test statistics for the generalized linear mixed model with the number of ants attending the caterpillar as the target variable.

\begin{tabular}{|c|c|c|c|c|c|c|c|}
\hline (A) Fixed effects & & $\boldsymbol{F}$ & & $d f 1$ & & $d f 2$ & $p$ \\
\hline Corrected model & & 26.624 & & 9 & & 226 & $<0.001$ \\
\hline Diet & & 5.092 & & 2 & & 179 & 0.007 \\
\hline Days after restriction & & 2.906 & & 1 & & 202 & 0.090 \\
\hline Caterpillar weight & & 24.662 & & 1 & & 178 & $<0.001$ \\
\hline Diet * Days after restriction & & 1.073 & & 2 & & 226 & 0.344 \\
\hline Diet * Caterpillar weight & & 0.081 & & 2 & & 226 & 0.922 \\
\hline Days after restriction * Caterpillar weight & & 0.521 & & 1 & & 177 & 0.471 \\
\hline (B) Pairwise contrasts & Contrast estimates & & Standard error & & $t$ & $d f$ & Adjusted $p$ \\
\hline Protein diet-Sugar diet & 4.946 & & 0.869 & & 5.691 & 11 & $<0.001$ \\
\hline Protein diet-Mixed diet & 6.962 & & 0.875 & & 7.952 & 14 & $<0.001$ \\
\hline Sugar diet-Mixed diet & 2.016 & & 0.670 & & 3.007 & 14 & $<0.001$ \\
\hline
\end{tabular}

(A) Fixed effects, (B) Pairwise contrasts for the categorical effect "diet."

Securing protein for growth may be at a premium when a queen is present laying eggs, but it is possible that the colony has a feedback mechanism that decreases worker motivation to forage on protein sources once the queen has been removed.

Several lines of evidence indicate that highly ant-associated lycaenids, such as J. evagoras, are especially attractive to tending ants because they provide a significant source of proteins rather than just carbohydrates (e.g., Pierce et al., 1991). For example, larvae reared on potted host plants to which fertilizer had been applied, thereby creating higher quality foliage (as measured by percent nitrogen, phosphorous and a number of other components), were significantly more attractive to ants than larvae reared on potted host plants with lower quality foliage that had not been treated with fertilizer, and these higher quality plants are more attractive to ovipositing females (Baylis and Pierce, 1991). Food quality also modifies the rate of dorsal nectary organ secretions in larvae of the myrmecophilous lycaenid Polyommatus icarus (Burghardt and Fiedler, 1996). Antassociated lycaenid species are more likely to feed on legumes and other nitrogen-fixing host plants than species whose larvae do not associate with ants (Pierce, 1985). Yet in the experiments presented here, colony fragments of I. mayri on the protein diet (i.e., the sugar-deficient diet) showed a stronger increase in the numbers of attending workers than those on the sugar diet (i.e., the protein-deficient diet). It is possible that carbohydrates are in general a more important nutrient for the ants, and the attendance experiment showed that the ants from the sugardeficient treatment treat the caterpillars of J. evagoras as a source of carbohydrates. Nevertheless, the increased caterpillar attendance by ants on the protein-deficient diet (compared to the control colony fragments on the mixed diet) shows that caterpillars are also an interesting source of amino acids. However, if simultaneous presence of several amino acids or their combination with carbohydrates is more attractive to the ants, then the relatively high concentration of serine in the caterpillars' secretions (approximately $50 \mathrm{mmol} / \mathrm{l}$; Pierce, 1985) is puzzling, as the caterpillars would not need to invest so heavily in a single amino acid.
The fact that ants vary the intensity of caterpillar attendance depending on their nutritional state raises the possibility for the caterpillars to maintain ongoing protection from predators and parasitoids through an adjustment of their secretions. For example, caterpillars of Zizeeria knysna adjust the secretion rate according to the phase of their interaction with the attendant ants, their own developmental stage, and the number of tending ants (Fiedler and Hagemann, 1992). In another ant-lycaenid butterfly association, larvae of the facultatively myrmecophilous butterfly Glaucopsyche lygdamus modify the amount of their secretions according to the species of tending ants (Axén, 2000). Providing ants with the necessary nutrients can allow myrmecophilous organisms to secure sufficient levels of protection. Increased provisioning with sugars (via more coccoid hemipterans) by Cordia alliodora myrmecophytic trees led to higher numbers of worker ants of Azteca pittieri per tree that protect the trees from herbivores (Pringle et al., 2011). When fed with more highly concentrated sugar solutions, workers of $A$. pittieri increased their aggressive potential toward herbivorous Cropia templada caterpillars. Caterpillars of J. evagoras might employ a similar strategy to prevent Iridomyrmex ants shifting their foraging interest toward alternative food sources. The differential interest of workers of I. mayri in attending caterpillars of J. evagoras could also reflect a different strategy of the caterpillars, providing secretions that include both sugars and amino acids, yet in a non-optimal $\mathrm{C}$ : $\mathrm{N}$ ratio with regard to the ants' needs. The skewed supply of nutrients then elicits more aggressive behavior in the ants toward other arthropods, increasing the protection for the caterpillars. In an ant-plant mutualism between the barrel cactus Ferocactus wislizeni and a guild of desert ants, the nutrient content of the cactus' extrafloral nectar was skewed toward high C: $\mathrm{N}$ ratios, and ants on a carbohydrate-rich diet were more aggressive against potential herbivores (Ness et al., 2009). If the larvae of J. evagoras were able to detect the specific nutritional needs of their attendant ants, they would benefit from modifying the composition of the nutrients in their secretions accordingly. By manipulating their secretions in this way, the 
larvae could alter ant attendance to adjust it to their own needs.

\section{AUTHOR CONTRIBUTIONS}

NP conceived the study. MF and NP designed and performed the experiments. SP, ME, and NP analyzed the data. SP, MF, ME, and NP wrote and revised the paper.

\section{FUNDING}

SP was supported by a post-doctoral fellowship funded by the Australian Research Council (DP120100162 to ME and NP). Cultivation of insects in the greenhouse was supported by grants from the Baker Fund and NSF DEB-9615760 to NP.

\section{REFERENCES}

Andersen, A. N., Hoffmann, B. D., and Berman, M. (2013). Diversity in the Australian ant genus Iridomyrmex MAYR, 1862 (Hymenoptera: Formicidae): a critique of HETERICK and SHATTUCK (2011), with particular reference to I. coeruleus HETERICK and SHATTUCK, 2011. Myrmecol. News 18, 103-111.

Axén, A. H. (2000). Variation in behavior of lycaenid larvae when attented by different ant species. Evol. Ecol. 14, 611-625. doi: 10.1023/A:1010975422243

Baylis, M., and Pierce, N. E. (1991). The effect of host-plant quality on the survival of larvae and oviposition by adults of an ant-tended lycaenid butterfly, Jalmenus evagoras. Ecol. Entomol. 16, 1-9. doi: 10.1111/j.1365-2311.1991.tb00186.x

Behmer, S. T. (2009). Insect herbivore nutrient regulation. Annu. Rev. Entomol. 54, 165-187. doi: 10.1146/annurev.ento.54.110807.090537

Bhatkar, A. P., and Whitcomb, W. H. (1970). Artificial diet for rearing various species of ants. Fla. Entomol. 53, 229-232. doi: 10.2307/3493193

Blüthgen, N., and Fiedler, K. (2004). Preferences for sugars and amino acids and their conditionality in a diverse nectar-feeding ant community. J. Anim. Ecol. 73, 155-166. doi: 10.1111/j.1365-2656.2004.00789.x

Braby, M. F. (2000). Butterflies of Australia: Their Identification, Biology and Distribution. Collingwood: CSIRO Publishing.

Brian, M. V. (1973). Feeding and growth in the ant Myrmica. J. Anim. Ecol. 42, 37-53. doi: $10.2307 / 3405$

Bristow, C. M., and Yanity, E. (1999). Seasonal response of workers of the Allegheny mound ant, Formica exsectoides (Hymenoptera: Formicidae) to artificial honeydews of varying nutritional content. Great Lakes Entomol. 32, 15-27.

Burghardt, F., and Fiedler, K. (1996). The influence of diet on growth and secretion behaviour of myrmecophilous Polyommatus icarus caterpillars (Lepidoptera: Lycaenidae). Ecol. Entomol. 21, 1-8. doi: 10.1111/j.1365-2311.1996.tb00259.x

Cassill, D. L., and Tschinkel, W. R. (1999a). "Information flow during social feeding in ant societies," in Information Processing in Social Insects, eds C. Detrain, J. L. Deneubourg, and J. M. Pasteels (Basel: Birkhäuser Verlag), 69-81.

Cassill, D. L., and Tschinkel, W. R. (1999b). Regulation of diet in the fire ant, Solenopsis invicta. J. Insect Behav. 12, 307-328. doi: 10.1023/A:1020835304713

Christensen, K. L., Gallacher, A. P., Martin, L., Tong, D., and Elgar, M. A. (2010). Nutrient compensatory foraging in a free-living social insect. Naturwissenschaften 97, 941-944. doi: 10.1007/s00114-010-0705-8

Cook, S. C., and Behmer, S. T. (2010). Macronutrient regulation in the tropical terrestrial ant Ectatomma ruidum (Formicidae): a field study in Costa Rica. Biotropica 42, 135-139. doi: 10.1111/j.1744-7429.2009.00616.x

Cook, S. C., Eubanks, M. D., Gold, R. E., and Behmer, S. T. (2010). Colony-level macronutrient regulation in ants: mechanisms, hoarding and associated costs. Anim. Behav. 79, 429-437. doi: 10.1016/j.anbehav.2009.11.022

Dussutour, A., Latty, T., Beekman, M., and Simpson, S. J. (2010). Amoeboid organism solves complex nutritional challenges. Proc. Natl. Acad. Sci. U.S.A. 107, 4607-4461. doi: 10.1073/pnas.0912198107

\section{ACKNOWLEDGMENTS}

We thank Roger and Bev Kitching for their generous support and hospitality while material used in this study was collected in the field. Michael Canfield assisted in collecting ant nests, and Ruby Hsu performed an earlier trial of this experiment that helped refine the methods. Christoph von Beeren, Mark Cornwall and Dany Zemeitat made helpful comments on the manuscript.

\section{SUPPLEMENTARY MATERIAL}

The Supplementary Material for this article can be found online at: http://journal.frontiersin.org/article/10.3389/fevo. 2016.00114

Dussutour, A., and Simpson, S. J. (2008). Carbohydrate regulation in relation to colony growth in ants. J. Exp. Biol. 211, 2224-2232. doi: 10.1242/jeb.017509

Dussutour, A., and Simpson, S. J. (2009). Communal nutrition in ants. Curr. Biol. 19, 740-744. doi: 10.1016/j.cub.2009.03.015

Eastwood, R., Pierce, N. E., Kitching, R. L., and Hughes, J. M. (2006). Do ants enhance diversification in lycaenid butterflies? Phylogeographic evidence from a model myrmecophile, Jalmenus evagoras. Evolution 60, 315-327. doi: 10.1111/ j.0014-3820.2006.tb01109.x

Evans, J. D., and Pierce, N. E. (1995). Effects of diet quality and queen number on growth in leptothoracine ant colonies (Hymenoptera: Formicidae) J. New York Entomol. Soc. 103, 91-99.

Fiedler, K., and Hagemann, D. (1992). The influence of larval age and ant number on myrmecophilous interactions of the African Grass Blue butterfly, Zizeeria knysna (Lepidoptera: Lycaenidae). J. Res. Lepidoptera 31, 213-232.

Fiedler, K., and Maschwitz, U. (1988). Functional analysis of the myrmecophilous relationships between ants (Hymenoptera: Formicidae) and lycaenids (Lepidoptera: Lycaenidae). II. Lycaenid larvae as trophobiotic partners of ants - a quantitative approach. Oecologia 75, 204-206. doi: 10.1007/BF003 78598

Fourcassié, V., and Traniello, J. F. A. (1994). Food searching behaviour in the ant Formica schaufussi (Hymenoptera, Formicidae): response of naive foragers to protein and carbohydrate food. Anim. Behav. 48, 69-79. doi: 10.1006/anbe. 1994.1212

Hendriksma, H. P., and Shafir, S. (2016). Honey bee foragers balance colony nutritional deficiencies. Behav. Ecol. Sociobiol. 70, 509-517. doi: 10.1007/ s00265-016-2067-5

Heterick, B. E., and Shattuck, S. (2011). Revision of the ant genus Iridomyrmex (Hymenoptera: Formicidae). Zootaxa 2845, 1-174.

Hoffmann, B. D., Andersen, A. N., and Zhang, X. (2011). Taxonomic confusion of two tramp ant species: Iridomyrmex anceps and Ochetellus glaber are really species complexes. Curr. Zool. 57, 662-667. doi: 10.1093/czoolo/57.5.662

Hojo, M. K., Pierce, N. E., and Tsuji, K. (2015). Lycaenid caterpillar secretions manipulate attendant ant behavior. Curr. Biol. 25, 2260-2264. doi: 10.1016/ j.cub.2015.07.016

Hojo, M. K., Wada-Katsumata, A., Ozaki, M., Yamaguchi, S., and Yamaoka, R. (2008). Gustatory synergism in ants mediates a species-specific symbiosis with lycaenid butterflies. J. Comp. Physiol. A 194, 1043-1052. doi: 10.1007/s00359008-0375-6

Hölldobler, B., and Wilson, E. O. (1990). The Ants. Cambridge, MA: Harvard University Press.

Howard, D. F., and Tschinkel, W. R. (1981). The flow of food in colonies of the fire ant, Solenopsis invicta: a multifactorial study. Physiol. Entomol. 6, 297-306. doi: 10.1111/j.1365-3032.1981.tb00274.x

Kay, A. (2004). The relative availabilities of complementary resources affect the feeding preferences of ant colonies. Behav. Ecol. 15, 63-70. doi: 10.1093/beheco/ $\arg 106$ 
Kitching, R. L. (1983). Myrmecophilous organs of the larvae and pupa of the lycaenid butterfly Jalmenus evagoras (Donovan). J. Nat. Hist. 17, 471-481. doi: 10.1080/00222938300770301

Ness, J. H., Morris, W. F., and Bronstein, J. L. (2009). For ant-protected plants, the best defense is a hungry offense. Ecology 90, 2823-2831. doi: 10.1890/08-1580.1

Pierce, N. E. (1985). Lycaenid butterflies and ants: selection for nitrogen-fixing and other protein-rich food plants. Am. Nat. 125, 888-895. doi: 10.1086/284387

Pierce, N. E. (1989). "Butterfly-ant mutualisms," in Toward a More Exact Ecology, eds P. J. Grubb and J. Whittaker (Oxford: Blackwell Scientific Publications), 299-324.

Pierce, N. E., Kitching, R. L., Buckley, R. C., Taylor, M. F. J., and Benbow, K. F. (1987). The costs and benefits of cooperation between the Australian lycaenid butterfly, Jalmenus evagoras, and its attendant ants. Behav. Ecol. Sociobiol. 21, 237-248. doi: 10.1007/BF00292505

Pierce, N. E., and Nash, D. R. (1999). "The Imperial Blue: Jalmenus evagoras (Lycaenidae)," in Biology of Australian Butterflies, eds R. L. Kitching, E. Sheermeyer, R. E. Jones, and N. E. Pierce (Collingwood: CSIRO Publishing), 277-313.

Pierce, N. E., Nash, D. R., Baylis, M., and Carper, E. R. (1991). "Variation in the attractiveness of Iycaenid butterfly larvae to ants," in Ant - Plant Interactions, eds C. R. Huxley and D. F. Cutler (Oxford: Oxford University Press), 131-142.

Porter, S. D. (1989). Effects of diet on the growth of laboratory fire ant colonies (Hymenoptera: Formicidae). J. Kansas Entomol. Soc. 62, 288-291.

Pringle, E. G., Dirzo, R., and Gordon, D. M. (2011). Indirect benefits of symbiotic coccoids for an ant-defended myrmecophytic tree. Ecology 92, 37-46. doi: 10.1890/10-0234.1

Raubenheimer, D., and Simpson, S. J. (1993). The geometry of compensatory feeding in the locust. Anim. Behav. 45, 953-964. doi: 10.1006/anbe.1993.1114

Raubenheimer, D., and Simpson, S. J. (1999). Integrating nutrition: a geometrical approach. Entomol. Exp. Appl. 91, 67-82. doi: 10.1046/j.15707458.1999.00467.x

Raubenheimer, D., Simpson, S. J., and Mayntz, D. (2009). Nutrition, ecology and nutritional ecology: toward an integrated framework. Funct. Ecol. 23, 4-16. doi: 10.1111/j.1365-2435.2009.01522.x

Seeley, T. D. (1989). Social foraging in honey bees: how nectar foragers assess their colony's nutritional status. Behav. Ecol. Sociobiol. 24, 181-199. doi: 10.1007/BF0 0292101

Simpson, S. J., Batley, R., and Raubenheimer, D. (2003). Geometric analysis of macronutrient intake in humans: the power of protein? Appetite 41, 123-140. doi: 10.1016/S0195-6663(03)00049-7

Simpson, S. J., Clissold, F. J., Lihoreau, M., Ponton, F., Wilder, S. M., and Raubenheimer, D. (2015). Recent advances in the integrative nutrition of arthropods. Annu. Rev. Entomol. 60, 293-311. doi: 10.1146/annurev-ento010814-020917

Simpson, S. J., and Raubenheimer, D. (1993). A multi-level analysis of feeding behaviour: the geometry of nutritional decisions. Phil. Trans. R. Soc. B 342, 381-402. doi: 10.1098/rstb.1993.0166

Simpson, S. J., and Raubenheimer, D. (2012). The Nature of Nutrition. Princeton: Princeton University Press.

Simpson, S. J., Sibly, R. M., Lee, K. P., Behmer, S. T., and Raubenheimer, D. (2004). Optimal foraging when regulating intake of multiple nutrients. Anim. Behav. 68, 1299-1311. doi: 10.1016/j.anbehav.2004.03.003

Smiley, J. T., Atsatt, P. R., and Pierce, N. E. (1988). Local distribution of the lycaenid butterfly, Jalmenus evagoras, in response to host ants and plants. Oecologia 76, 416-422. doi: 10.1007/BF00377037

Sorensen, A. A., Busch, T. M., and Vinson, S. B. (1985). Control of food influx by temporal subcastes in the fire ant, Solenopsis invicta. Behav. Ecol. Sociobiol. 17, 191-198. doi: 10.1007/BF00300136

Wada, A., Isobe, Y., Yamaguchi, S., Yamaoka, R., and Ozaki, M. (2001). Tasteenhancing effects of glycine on the sweetness of glucose: a gustatory aspect of symbiosis between the ant, Camponotus japonicus, and the larvae of the lycaenid butterfly, Niphanda fusca. Chem. Senses 26, 983-992. doi: 10.1093/ chemse/26.8.983

Wilder, S. M., and Eubanks, M. D. (2010). Extrafloral nectar content alters foraging preferences of a predatory ant. Biol. Lett. 6, 177-179. doi: 10.1098/rsbl. 2009.0736

Wilson, E. O. (1971). The Insect Societies. Cambridge, MA: Harvard University Press.

Conflict of Interest Statement: The authors declare that the research was conducted in the absence of any commercial or financial relationships that could be construed as a potential conflict of interest.

The reviewer KF and handling Editor declared their shared affiliation, and the handling Editor states that the process nevertheless met the standards of a fair and objective review.

Copyright (c) 2016 Pohl, Frederickson, Elgar and Pierce. This is an open-access article distributed under the terms of the Creative Commons Attribution License (CC BY). The use, distribution or reproduction in other forums is permitted, provided the original author(s) or licensor are credited and that the original publication in this journal is cited, in accordance with accepted academic practice. No use, distribution or reproduction is permitted which does not comply with these terms. 